\title{
Optimum Allocation of Agricultural Land to the Vegetable Crops under Uncertain Profits using Fuzzy Multiobjective Linear Programming
}

\author{
P.Lavanya Kumari ${ }^{1}$, G.Krishna Reddy ${ }^{2}$ and T.Giridhara Krishna ${ }^{3}$ \\ ${ }^{1}$ Scientist (Statistics) \\ ${ }^{2}$ Principal Scientist (Agronomy), ${ }^{3}$ Associate Director of Research, Regional Agricultural Research Station, \\ Acharya N.G.Ranga Agricultural University, Tirupati-517502
}

\begin{abstract}
Decision making in agriculture had been embedded with a scientific planning for higher yields to cater the needs of overwhelming population and higher benefits for the prosperity of the farmers. The optimal cropping pattern that is allocation of land to various crops by making use of limited resources has become majorchallenge to fetch higher profits. Traditionally, farmers have relied on experience, intuition and comparisons with their neighbors to make decisions regarding cropping pattern. Basically,profit is a function of many factors which are sometimes beyond our control; hence intuitionand experience do not guarantee the optimal (maximum) profits. Many researches provided the optimum cropping patterns using Linear Programming (LP) technique in case of fixed prices (profits) of crops. But volatility in prices is very high for vegetable crops (cash crops) due to their expensive cultivation with high risk of profitability despite enhanced profits over food crops.Uncertainty in prices has countless impact on net returns ofcrops in agriculture. This paper aimed to provide a procedure for handling the volatility in profits of vegetable crops using Fuzzy Multi objective Linear Programming (FMOLP) along with step wise procedure to solve the model very easily using solver tool in MS-Excel. Numerical example cited in this paper is based on crisp profit coefficients and their chance of occurrence (probability) observedover period.
\end{abstract}

Key words: Optimum Land allocation, Multiobjective LPP, Uncertain profits, Solver in Excel.

\section{Introduction}

The quantities of yield produced from agriculture farms and demand for that commodity influence the market prices significantly. Generally farmers follow a traditional method for a cropping pattern or allocation of land to various crops varies depending onthe available resources. Over the decade it has been observed that the net profit per acre is greater in vegetable crops (cash crops) than that of food crops. Thus for each cultivation pattern of vegetable crops, maximization of the profit will be the major objective of any farmer. These problems of allocation of land for different crops, maximization of production of crops, maximization of profit, minimization of production cost are addressed in agricultural management system with the help of Operations Research approach particularly with Linear programming Problem (LPP), Integer Programming problem(IPP), Assignment problem(AP) and Transportation Problem (TP). Initially, these problems of agriculture sector were modeled as single objective linear programming problem by dealing with one objective at a time. But with changing scenario of multifaceted real time problems, several objectives need to be handled simultaneously subject to the same set of constraints. Thus, the situation demands for new methodologies which are capable in handling the complex problem of decision making, as the maximization of crop production can't guarantee the maximization of profit. In the agriculture sector, profit or loss also depend on fluctuating demand, supply and pricing of a particular crop with minimization of cost of cultivation needed for that crop. Thus the maximization of profit turns out to be a multiobjective decision making problem.

The success of aneconomic model depends on the fact that how effectively it can sustain for volatility of market prices. Thus, a good model must accommodate the conditions of uncertainty and complexity, while handling imprecise information. For example, in financial engineering, the stock market prices aretreated as random variable and the efforts are provided for optimal plans with guaranteed return. Similarly, management of agribusiness plans at farmer's level are very much needed to achieve the guaranteed returns despite the price fluctuations. In general food grains prices are not much volatile in nature and give almost guaranteed return, as in many countries (India) food grains have government support prices, whereas vegetable prices are mostly random variables and its cropping is also highly cost effective. In fact the vegetable cropping needs to manage the several costs viz., capital investment in insecticides, pesticides, fertilizers, frequent irrigation, labours and transportation cost. Sometimesunexpected production of same crops from local areas will also influence the market prices due lack of storagefacility. Surprisingly vegetable prices also vary on day to day basis even in the same season. By keeping in view of volatility ofvegetable prices, a proper land planning is initiated for optimal returns. 


\section{Literature Review}

In present scenario, LPP is usedfor all sorts of decision making problems regarding production, distribution, marketing and policy decision making since it is perhaps the most important and best-studied optimization problem. Scarpari and Beaclair in the year 2010 argued that, "Optimized agricultural planning is a fundamental activity in business profitability because it can increase the returns from an operation with low additional costs". In management science several approaches have been developed to deal with multiobjective decision making problem. Among them, Vector maximum method, Goal programming and Interactive techniques are the three important and widely used methodologies to deal with MOLP problems. Bellmann and Zadeh [1970] provided anorigin for decision making in fuzzy based environment whereas a new approach to the problem definition for finding a compromise solution to MOLP problem was initiated by Zimmermann [1978]. The proposition of this regard was to explore a compromise solution of MOLPP. The methodologies of obtaining compromise solution was further developed in various directions by Buckley [1983], Luhandjula [1982], Sakawa and Yano [1986], Chanas [1989] using various type of membership functions.Radhakrishnan D [1962] and Raj Krishna [1963] proposed the LP technique for addressing the optimal farm planning. Andres Weintraub and Carlos Romero [2006] analyzed the use of operations research models to assess the past performance in the field of agricultural and forestry and highlighted the current problems and future score of research. (Tanko L. et.al. [2006]) concentrated on planning problems at the farm and regional-sector level, environmental implications, risk and uncertainty issues, multiple criteria, and the formulation of livestock rations and feeding stuffs. Itohet. al. [2003] considered a problem of crop planning under uncertainty assuming profit coefficients are discrete random variables and proposed a model to obtain maximum and minimum value of gains for decision maker.

In domain of agricultural production system, where uncertainty and vagueness play a major role in decision making, several researchers such as Slowinski [1986], Sinha et al. [1988], Sher and Amir [1994], Sumpsi et.al. [1996], Sarkeret. al. [1997], Pal and Moitra [2003], Vasant [2003], Biswas and Pal [2005] used fuzzy goal programming techniques for a farm planning problem. Kruse and Meyer [1987] attracted researchers to study agricultural crop planning with stochastic values as stochastic linear programming problem to address such problems. Hulsurkaret. al. [1997] studied the fuzzy programming approach to multiobjective stochastic linear programming problem. Lodwicket. al.[2000] made a comparison of fuzzy, stochastic and deterministic methods in a case of crop planning problem followed by a study of Itoh and Ishii [2001] based on possibility measure. Toyonagaet. al.[2005] studied a crop planning problem with fuzzy random profit coefficients. Dinesh K.Sharmaet. al.[2007] studied FGP for agricultural land allocation problem and proposed an annual agricultural plan for different crops.AnjeliGarg, Shiva Raj Singh [2011] provided a procedure to solve MOLP using MaxMin approach to build up the membership function and stated that it provides superior results than that of Itoh et. al. [2003]

A combined application of General Information System and linear programming for strategic planning of agricultural uses was carried out by Campbell et al. [1992]. The land use planning techniques and methodologies with different objectives, applications, and land uses have been identified by Santé I and Crecente R [2005]. Keith Butterworth [1985] suggested that in the current economic climate, linear programming could well be worth reconsidering as a maximizing technique in farm planning. This particularly applies when it is used in conjunction with integer programming, which allows many of LP's problems to be overcome. Felix Majeke and Judith Majeke [2010] used an LP model for farm resource allocation. A LP crop mix model for a finite-time planning horizon under limited available resources such as budget and land acreage, the crop-mix planning model was formulated and transformed into a multi-period LP problem by NordinHj. Mohamad and Fatimah Said [2011] to the maximize the total returns at the end of the planning horizon. Ion RalucaAndreea and TurekRahoveanu Adrian [2012] suggested LP method to determine the optimal structure of crops, different methods which take into account the income and expenditure of crops per hectare were used for optimizing profit. They observed that, after applying the econometric model the profit rose to $143 \%$ and costs reduced to $81 \%$.

\subsection{Problem Description}

\section{Methodology}

Let us consider the problem in which number of producible of crops are ' $\mathrm{n}$ ' and respective profits for these crops are $\mathrm{c}_{\mathrm{i}}, c_{i 2}, c_{i 3} \ldots \ldots \ldots c_{i n}$ per unit area along with respective probabilities $\mathrm{p}_{\mathrm{i}}$. The decision variable $x_{j}$, element $h_{j}$ and $w_{j}$ denote cultivation area for crop $\mathrm{j}$, the work time in labour hours and required water units for growing crop $\mathrm{j}$ at the unit area respectively. As the land of a farm is limited $x_{1}+x_{2}+x_{3}+x_{4}+\ldots \ldots x_{n}$ has to be less than or equal to 'L'acres and we call it as "land constraint". The total labour hours of working time is limited and thus $h_{1} x_{1}+h_{2} x_{2}+h_{3} x_{3}+h_{4} x_{4}+\ldots \ldots .+h_{n} x_{n}$ has to be less than or equal to a certain ' $\mathrm{H}$ ' and we call it as "labour constraint". Similarly, water is also another constraint of having ' $\mathrm{W}$ ' units and the total requirement must be adjusted within the limit, then equation $w_{1} x_{1}+w_{2} x_{2}+w_{3} x_{3}+w_{4} x_{4}+\ldots \ldots .+w_{n} x_{n}$ can be treated as "water 
constraint". Under these constraints and discrete crisp and fuzzy random profit coefficients, we want to find the decision variables $x_{j}$ so as to maximize the profit(R).

Maximize $\mathrm{R}$

Subject to

$$
\left.\begin{array}{l}
x_{1}+x_{2}+x_{3}+\ldots \ldots \leq L \quad \text { (Land constraint) } \\
h_{1} x_{1+} h_{2} x_{2}+h_{3} x_{3}+\cdots \ldots+h_{n} x_{n} \leq H \text { (Labour constraint) } \\
w_{1} x_{1+} w_{2} x_{2}+w_{3} x_{3}+\ldots \ldots .+w_{n} x_{n} \leq W \text { (Water constraint) }
\end{array}\right\}
$$

\subsection{Fuzzy Programming\& Max-Min approach}

Generally in fuzzy environment a decision is considered as a fuzzy objective function, characterized by its membership function. The similar approach is also applied to the constraints. In case of several objectives, a procedure of selection of activities comes into existence which simultaneously satisfies all the objective functions and the constraints. This process can be viewed as combination of fuzzy constraints as well as fuzzy objective functions. Further, the membership function of the solution set is used to maximize decision to a level of satisfaction. The present work on optimization under uncertainty in agriculture production planning has been studied in a situation when profit coefficients are crisp discrete random variables using max-min approach of fuzzy programming developed by Zimmermann [1978].According to him if the objective function is

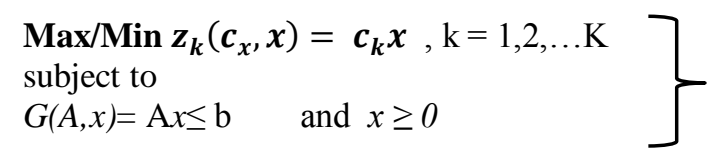

wherec $_{k}=\left(c_{k 1}, c_{k 2}, \ldots \ldots \ldots . c_{k n}\right)$ is the vector of profit/cost coefficients of the $\mathrm{k}^{\text {th }}$ objective function and $\mathrm{b}=\left[\mathrm{b}_{1}, \mathrm{~b}_{2}, \mathrm{~b}_{3} \ldots \mathrm{b}_{\mathrm{m}}\right]^{\mathrm{T}}$ is the vector of total resources available $x=\left[x_{1}, x_{2}, x_{3} \ldots x_{\mathrm{m}}\right]^{\mathrm{T}}$ is parameter of decision variable and $\mathrm{A}=\left[\mathrm{a}_{\mathrm{ij}}\right]_{\mathrm{mxn}}$ is matrix of coefficients. He proposed mad-min operator to solve MOLP problem and considered the equation as

find $\mathbf{x}$, such that $z_{k}(x) \geq z_{k}^{0} \forall k, x \in X$

where $z_{k}^{0} \forall k$ are corresponding goals and all objective functions are to be maximized . Here objective functions of equation (3.2.1) are considered as fuzzy constraints. If the tolerances of fuzzy constraints are given, one can establish their membership function $\mu_{k}(x), \forall k$ and then a feasible solution set is characterized by its membership function

$\mu_{D}(x)=\min \left\{\mu_{1}(x), \mu_{k 2}(x), \mu_{3}(x) \ldots \ldots \ldots \mu_{k}(x)\right\}$

Now, a decision maker makes a decision with a maximum $\mu_{D}$, then the problem will become

$\operatorname{Max} \mu_{D}(x)$, subject to $\max \left[\min _{\mathrm{k}} \mu_{k}(x)\right]$ such that $x \in X$, let $\alpha=\min _{\mathrm{k}} \mu_{k}(x)$ be the overall satisfactory level of compromise. We obtain the following equivalent model as

$\left.\begin{array}{l}\operatorname{Max} \boldsymbol{\alpha} \\ \text { such that } \alpha \leq \mu_{k}(x), \forall k \\ x \in X\end{array}\right\}$

where, a membership functions of objective functions is estimated by obtaining payoff table of Positive Ideal Solution(PIS) and assume that membership functions are of type non decreasing linear/hyperbolic etc.

\subsection{Computational algorithmto solve a Fuzzy MOLP}

A computational algorithm for a scenario when profit coefficients are crisp discrete random variables by using fuzzy multiobjective linear programming approach (AnjeliGarg, Shiva Raj Singh ) is given below Step-1:Solve each objective function with the same set of constraintsprovidedin (3.1.1) separately.

Step-2: Using the solution obtained in step1, find the corresponding value of all the objective functions for each of solution. 
Step-3:From step 2, obtain the lower and upper bounds $z_{k}^{\prime}$ and $z_{k}^{*}$ for each objective function and construct a table of Positive Ideal Solution (PIS).

Step-4:Consider a linear and non-decreasing membership function between $z_{k}^{\prime}$ and $z_{k}^{*}, \forall \mathrm{k}$ as

$$
\mu_{k}(x)=\left\{\begin{array}{cc}
1 & \text { if } z_{k}(x)=z_{k}^{\prime} \\
\frac{\left[z_{k}(x)-z_{k}^{\prime}\right]}{\left[z_{k}-z_{k}^{\prime}\right]} & \text { if } z_{k}^{\prime} \leq z_{k}(x) \leq z_{k}^{*} \\
0 & \text { if } z_{k}(x)<z_{k}^{\prime}
\end{array}\right.
$$

The above membership function is essentially based on the concept of preference/satisfaction.

Step-5:Transformmultiobjective linear programming into LPP as

\section{$\operatorname{Max} \alpha$}

Subject to

$x_{1}+x_{2}+x_{3}+\cdots \ldots x_{n} \leq L \quad$ (Land constraint)

$h_{1} x_{1+} h_{2} x_{2}+h_{3} x_{3}+\cdots \ldots .+h_{n} x_{n} \leq H$ (Labour constraint)

$w_{1} x_{1+} w_{2} x_{2}+w_{3} x_{3}+\cdots \ldots .+w_{n} x_{n} \leq W$ (Water constraint)

$\mu_{k}(x)=\left\{\frac{\left[z_{k}(x)-z_{k}^{\prime}\right]}{\left[z_{k}-z_{k}^{\prime}\right]} \geq \alpha, x \in X\right.$

Where $_{k}(x)=c_{k 1} x_{1}+c_{k 2} x_{2}+c_{k 3} x_{3}+\cdots \ldots+c_{k n} x_{n}$

Further equation (3.3.1)can be written as

$\operatorname{Max} \alpha$

Subject to

$x_{1}+x_{2}+x_{3}+\cdots \ldots x_{n} \leq L \quad$ (Land constraint)

$h_{1} x_{1+} h_{2} x_{2}+h_{3} x_{3}+\cdots \ldots .+h_{n} x_{n} \leq H \quad$ (Labour constraint)

$w_{1} x_{1+} w_{2} x_{2}+w_{3} x_{3}+\cdots \ldots+w_{n} x_{n} \leq W \quad$ (Water constraint)

$c_{11} x_{1}+c_{12} x_{2}+c_{13} x_{3}+\cdots \ldots+c_{1 n} x_{n}-\alpha\left(z_{1}^{*}-z_{1}^{\prime}\right) \geq z_{1}^{\prime}$

$c_{21} x_{1}+c_{22} x_{2}+c_{23} x_{3}+\cdots \ldots+c_{2 n} x_{n}-\alpha\left(z_{2}^{*}-z_{2}^{\prime}\right) \geq z_{2}^{\prime}$

$c_{31} x_{1}+c_{32} x_{2}+c_{33} x_{3}+\cdots \ldots+c_{3 n} x_{n}-\alpha\left(z_{3}^{*}-z_{3}^{\prime}\right) \geq z_{3}^{\prime}$

$c_{m 1} x_{1}+c_{m 2} x_{2}+c_{m 3} x_{3}+\cdots \ldots+c_{m n} x_{n}-\alpha\left(z_{m}^{*}-z_{m}^{\prime}\right) \geq z_{m}^{\prime}$

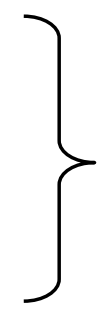

Step-6:Equation (3.3.2) t can be solved easily using Solver module in MS-Excel and the Procedureisprovided in next section.

Step-7: Finally, the guaranteed expected return can be calculated as $\sum_{i=1}^{k} z_{i}(x) p_{i}$, where $z_{i}(x)$ is the value of the $i^{\text {th }}$ objective function at the values of decisionvariables obtained from the solution of equation (3.3.2).

\subsection{About Solver in MS Excel}

Solver is a part of a suite of commands sometimes called what-if analysis. With Solver, one can find an optimal value for a formula in one cell called the target cell on a worksheet. Solver works with a group of cells that are related, either directly or indirectly, to the formula in the target cell. Solver adjusts the values in the changing cells specified, called the adjustable cells to produce the result specified from the target cell formula. One can apply constraints to restrict the values Solver can use in the model, and the constraints can refer to other cells that affect the target cell formula. Use Solver to determine the maximum or minimum value of one cell by changing other cells, for example, one can change the amount of your projected advertising budget and see the effect on your projected profit amount.

\subsubsection{Supporting Terminology of Solver}

What -if-analysis tools: A process of changing the values in cells to see how those changes affect the outcome of formulas on the worksheet.

Formula: A sequence of values, cell references, names, functions, or operators in a cell that together produce a new value. A formula always begins with an equal sign (=). 
Constraints: The limitations placed on a Solver problem. One can apply constraints toadjustable cells, the target cell, or other cells that are directly or indirectlyrelated to the target cell.

\subsubsection{How to install Solver in Excel}

Excel has a built-in statistical package for carrying out LPP.This feature is usually hiden and can be brought out to the menu by clicking the button sequencing.

Open Excels heet $\rightarrow$ Office button/File $\rightarrow$ Excel options $\rightarrow$ Add- ins $\rightarrow$ analysis tool pack and solver add-in $\rightarrow$ ok.(the process varies from version to version).

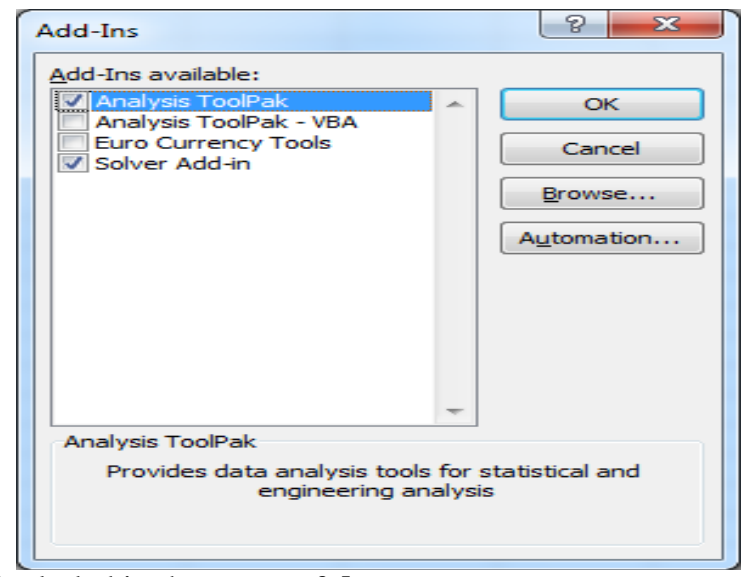

Automatically solver can be included in the menu of data.

\section{Results and Discussion}

\subsection{Numerical illustration -Problem description}

A farmer has 12 acres of cultivable land and he wanted to grow multiple vegetable crops viz., Brinjal, Ladies finger, Bitter guard and Tomato in a season. Out of his experience, he stated that labour work time available with him is 220 hours and availability of water is 25 acre-inches. The profit coefficients (lakh rupees), requiredwork time and water for each crop for one acre of land are provided in the Table-4.1. How many acres he has to consider for each crop in order to get guaranteed net returns out of volatility among profit coefficients?

Table-4.1: Profit coefficients, labour requirement and water for entire duration of crop

\begin{tabular}{|c|c|c|c|c|c|}
\hline & Brinjal & $\begin{array}{c}\text { Ladies } \\
\text { finger }\end{array}$ & Bitter guard & Tomato & Probability \% \\
\hline Profit coefficients (lakh rupees) (set 1) & 0.35 & 0.32 & 0.69 & 0.95 & 40 \\
\hline Profit coefficients (lakh rupees)(set 2) & 0.55 & 0.41 & 0.78 & 1.20 & 25 \\
\hline Profit coefficients (lakh rupees)(set 3) & 0.65 & 0.53 & 1.02 & 0.68 & 15 \\
\hline Profit coefficients (lakh rupees)(set 4) & 0.82 & 0.62 & 1.25 & 0.80 & 20 \\
\hline labour requirement per acre ('000 hours) & 1.760 & 1.280 & 1.600 & 1.840 & 18 \\
\hline Waterrequirement per acre (acre-inch) & 27.2 & 17.5 & 18.2 & \\
\hline
\end{tabular}

Here, we illustrate solution of the problem by the working procedure provided in the section-3.3. Let $x_{1}$, $x_{2}, x_{3}$ and $x_{4}$ be the no.of acres to be considered for Brinjal, Ladies finger, Bitter guard and Tomato respectively and the undertaken problem is to solve

Maximize $\mathrm{Z}_{1}=0.35 \mathrm{x}_{1}+0.32 \mathrm{x}_{2}+0.69 \mathrm{x}_{3}+0.95 \mathrm{x}_{4}$ Maximize $\mathrm{Z}_{2}=0.55 \mathrm{x}_{1}+0.41 \mathrm{x}_{2}+0.78 \mathrm{x}_{3}+1.20 \mathrm{x}_{4}$ Maximize $Z_{3}=0.65 x_{1}+0.53 x_{2}+1.02 x_{3}+0.68 x_{4}$ Maximize $Z_{4}=0.82 x_{1}+0.62 x_{2}+1.25 x_{3}+0.80 x_{4}$ Subject to constraints $\mathrm{x}_{1}+\mathrm{x}_{2}+\mathrm{x}_{3}+\mathrm{x}_{4} \leq 12$ (Land constraint)

$1.76 \mathrm{x}_{1}+1.28 \mathrm{x}_{2}+1.60 \mathrm{x}_{3}+1.84 \mathrm{x}_{4} \leq 25$ (Labour constraint)

$27.2 \mathrm{x}_{1}+17.5 \mathrm{x}_{2}+18.5 \mathrm{x}_{3}+18.0 \mathrm{x}_{4} \leq 220$ (Water constraint)

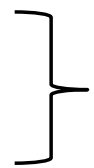

$\mathrm{x}_{1}, \mathrm{x}_{2}, \mathrm{x}_{3}, \mathrm{x}_{4} \geq 0$ 


\subsection{Working procedure of the methodology provided in section 3.3 using Solver}

Step-1 in section 3.3 can be achieved by the following way

a. Open Excel sheet and type the decision variables $\left(\mathrm{X}_{1}, \mathrm{X}_{2}, \mathrm{X}_{3}\right.$ and $\left.\mathrm{X}_{4}\right)$ and names of the constraints (Land, labour hours and water) in the cells A3 to A6 and E3 to E5 asshown in MS-Excel Screen-2.

b. From B3 to B6 enter zeros and From F3 to F5 type the constraints given in (4.1.2) byusing respective cell addresses for decision variables starting with(equal to) "=" symbol.

For example: in cell F3 type "=B3+B4+B5+B6" (without quotes) and in cell $\mathrm{F} 4$ enter " $=1.76 * \mathrm{~B} 3+1.28 * \mathrm{~B} 4+1.6 * \mathrm{~B} 5+1.84 * \mathrm{~B} 6 "$ and in cell $\mathrm{F} 5$ enter " $=27.2 * \mathrm{~B} 3+17.5 * \mathrm{~B} 4+18.2 * \mathrm{~B} 5+18 * \mathrm{~B} 6 "$

c. Similarly in the cells B9 to B12 type Max $Z_{1} /\left(Z_{1}\right)_{1},\left(Z_{2}\right)_{1},\left(Z_{3}\right)_{1}$, and $\left(Z_{4}\right)_{1}$ respectively as shown in MSExcel Screen-2. Further, enter equations of four objective functions fromC9 to C12as

$$
\begin{aligned}
& "=0.35 * \mathrm{~B} 3+0.32 * \mathrm{~B} 4+0.69 * \mathrm{~B} 5+0.95 * \mathrm{~B} 6 " \\
& "=0.55 * \mathrm{~B} 3+0.41 * \mathrm{~B} 4+0.78 * \mathrm{~B} 5+1.20 * \mathrm{~B} 6 " \\
& "=0.65 * \mathrm{~B} 3+0.53 * \mathrm{~B} 4+1.02 * \mathrm{~B} 5+0.68 * \mathrm{~B} 6 " \text { and } \\
& "=0.82 * \mathrm{~B} 3+0.62 * \mathrm{~B} 4+1.25 * \mathrm{~B} 5+0.80 * \mathrm{~B} 6 " \text { respectively. }
\end{aligned}
$$

d. In main menu of Excel,Goto Data $\rightarrow$ Solver and set objective function as $\$ C \$ 9$, by changing variable cells\$B \$3:\$B $\$ 6$ as shown in MS-Excel Screen-1(a) by selecting respective cells. For subject to the constraints click on Add button and in the resultant window(MS Excel Screen-1(b)) select F3 cell and enter 12 in the right side of the inequation. We can select the respective symbols ofinequations $(<=,=,>=)$ as per ourrequirements.

e. After entering all constraints, select Make unconstrained variables Non-Negative andSelect Simplex LP and click on solve. Then window with the message Solver found a solution will be appeared as shown MS Excel screen-1(c) and click on Ok. Optimum solution withregard to the first objective funcation willl appear in cells C9:C12 as shown in MS Excel Screen-2.

f. Copy the optimum solution and reset the decision variables values as zero in order to runthe same for the second objective function. Change the set objective cell as \$C\$10 and rerunthe solver and continue for the third and fourth objective functions also as \$C\$11 and \$C\$12.

Step-2 in section 3.3 can be achieved by copying Max $\mathrm{Z}_{1} /\left(\mathrm{Z}_{1}\right)_{1},\left(\mathrm{Z}_{2}\right)_{1},\left(\mathrm{Z}_{3}\right)_{1}$, and $\left(\mathrm{Z}_{4}\right)_{1}$ valuesavailable in cells C9 to $\mathrm{C} 12$ immediately after running solver for each Objective function.

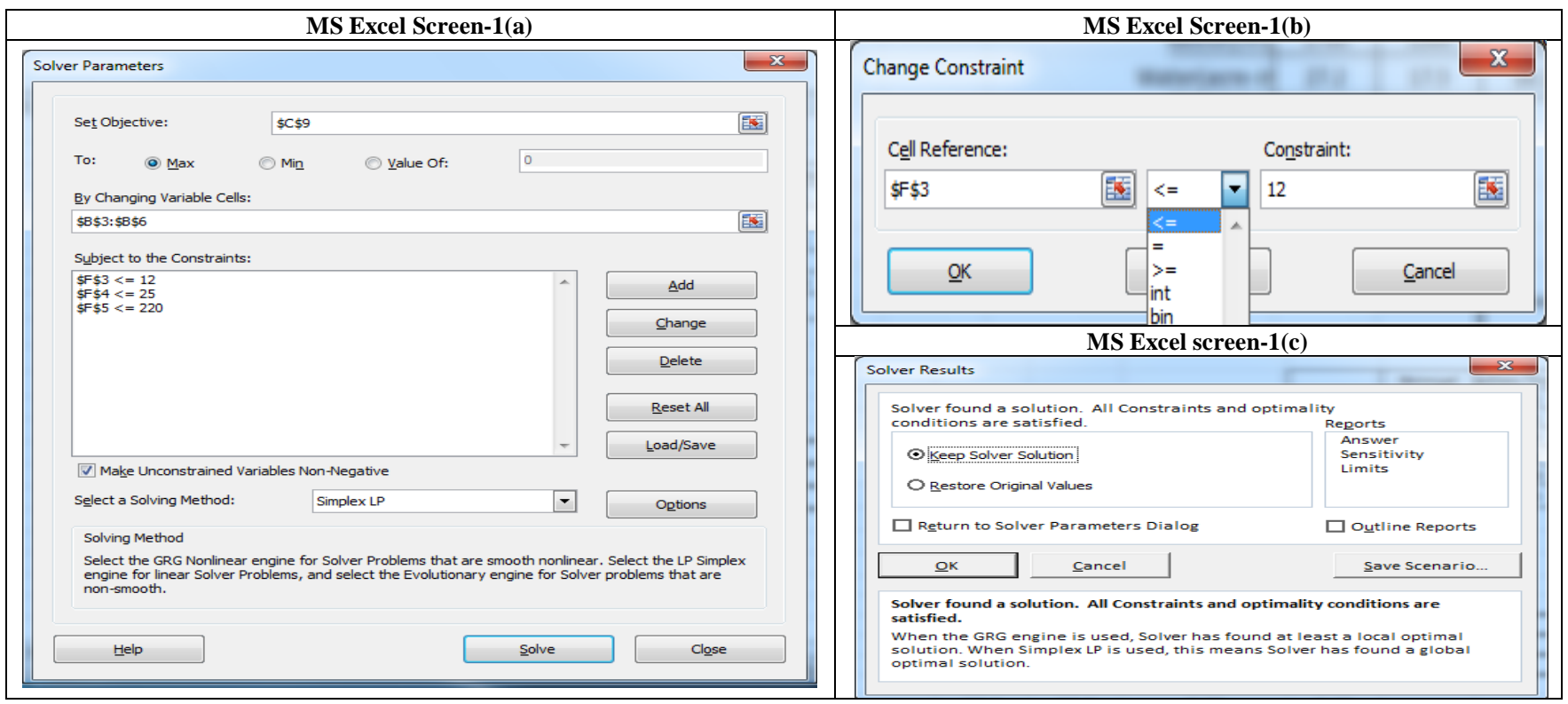




\begin{tabular}{|c|c|c|c|c|c|c|c|c|c|c|c|c|c|c|c|}
\hline \multicolumn{8}{|c|}{ MS Excel Screen-2(a) } & \multicolumn{8}{|c|}{ MS Excel Screen-2(b) } \\
\hline 4 & A & B & c & D & E & $\mathrm{F}$ & G & 4 & A & B & $C$ & D & $E$ & $\mathrm{~F}$ & G \\
\hline 1 & \multicolumn{6}{|c|}{ Solving LPP with Objective function Z1 using Solver } & & 1 & \multicolumn{6}{|c|}{ Solving LPP with Objective function Z1 using Solver } & \\
\hline 2. & & & & & & & & 2. & & & & & & & \\
\hline 3 & $x 1=$ & 0 & & & constraint $($ Land $)=$ & 0 & & 3 & $x 1=$ & 0 & & & constraint(Land) $=$ & 12 & \\
\hline 4 & $x 2=$ & 0 & & & Constraint(labour hours) $=$ & 0 & & 4 & $x 2=$ & 0 & & & Constraint(labour hours) $=$ & 22.08 & \\
\hline 5 & $x 3=$ & 0 & & & Constraint(Water) $=$ & 0 & & 5 & $x 3=$ & 0 & & & Constraint(Water) $=$ & 216 & \\
\hline 6 & $x 4=$ & 0 & & & & & & 6 & $x 4=$ & 12 & & & & & \\
\hline 7 & & & & & & & & 7 & & & & & & & \\
\hline 8 & & & & & & & & 8 & & & & & & & \\
\hline 9 & & $\operatorname{Max} Z_{1} /\left(Z_{1}\right)_{1}$ & 0 & & & & & 9 & & $\operatorname{Max} Z_{1} /\left(Z_{1}\right)_{1}$ & 11.4 & & & & \\
\hline 10 & & $\left(Z_{2}\right)_{1}$ & 0 & & & & & 10 & & $\left(Z_{2}\right)_{1}$ & 14.4 & & & & \\
\hline 11 & & $\left(Z_{3}\right)_{1}$ & 0 & & & & & 11 & & $\left(Z_{3}\right)_{1}$ & 8.16 & & & & \\
\hline 12 & & $\left(Z_{4}\right)_{1}$ & 0 & & & & & 12 & & $\left(Z_{4}\right)_{1}$ & 9.6 & & & & \\
\hline 13 & & & & & & & & 13 & & & & & & & \\
\hline
\end{tabular}

The Optimal solution to this crisp LP Problem for the first objective function with regard to constraints using (4.1.2) is $\mathrm{x}_{1}=0, \mathrm{x}_{2}=0 \mathrm{x}_{3}=0 \mathrm{x}_{4}=12 \quad\left(\mathrm{Z}_{1}\right)_{1}=11.4$. The four optimum solutions are summarized in Table-4.2.

\begin{tabular}{|c|c|c|c|c|}
\hline \multicolumn{5}{|c|}{ Table-4.2: Solutions at each objective function } \\
\hline & Max $\mathrm{Z}_{1}$ & $\operatorname{Max} \mathrm{Z}_{2}$ & $\operatorname{Max} \mathrm{Z}_{3}$ & Max $\mathrm{Z}_{4}$ \\
\hline $\mathrm{X}_{1}$ & 0 & 0 & 0 & 0 \\
\hline $\mathrm{X}_{2}$ & 0 & 0 & 0 & 0 \\
\hline $\mathrm{X}_{3}$ & 0 & 0 & 12 & 12 \\
\hline $\mathrm{X}_{4}$ & 12 & 12 & 0 & 0 \\
\hline
\end{tabular}

Step-3 in section 3.3 can be obtained by arranging solutions at each objective function solved with regard to constraints using (4.1.2) and are summarized in Table-4.3.

\begin{tabular}{|c|c|c|c|c|c|c|c|}
\hline \multicolumn{7}{|c|}{ Table-4.3: Positive Ideal Solutions } \\
\hline & $\begin{array}{c}\text { Max } \\
\mathrm{Z}_{1}\end{array}$ & $\begin{array}{c}\text { Max } \\
\mathrm{Z}_{2}\end{array}$ & $\begin{array}{c}\text { Max } \\
\mathrm{Z}_{3}\end{array}$ & $\begin{array}{c}\text { Max } \\
\mathrm{Z}_{4}\end{array}$ & Max & Min & $\begin{array}{c}\text { Max - } \\
\text { Min })\end{array}$ \\
\hline $\mathrm{Z}_{1}$ & $11.4^{*}$ & 11.4 & $8.28^{\prime}$ & 8.28 & 11.4 & 8.28 & 3.12 \\
\hline $\mathrm{Z}_{2}$ & $14.4^{*}$ & 14.4 & $9.36^{\prime}$ & 9.36 & 14.4 & 9.36 & 5.04 \\
\hline $\mathrm{Z}_{3}$ & $8.16^{\prime}$ & 8.16 & $12.24^{*}$ & 12.24 & 12.24 & 8.16 & 4.08 \\
\hline $\mathrm{Z}_{4}$ & 9.6 & 9.6 & $15^{*}$ & 15 & 15 & 9.6 & 5.4 \\
\hline & $\mathrm{X}_{1}$ & $\mathrm{X}_{2}$ & $\mathrm{X}_{3}$ & $\mathrm{X}_{4}$ & & & \\
\hline
\end{tabular}

Step-4and5 in section 3.3 will help to reformulate the problem, it reduces to a LPP as

\section{Maximize $\alpha$}

Subject to

$\mathrm{X}_{1}+\mathrm{X}_{2}+\mathrm{X}_{3}+\mathrm{X}_{4} \leq 12$

$1.76 \mathrm{x}_{1}+1.28 \mathrm{x}_{2}+1.60 \mathrm{x}_{3}+1.84 \mathrm{x}_{4} \leq 25$

$27.2 \mathrm{x}_{1}+17.5 \mathrm{x}_{2}+18.5 \mathrm{x}_{3}+18.0 \mathrm{x}_{4} \leq 220$

$0.35 \mathrm{x}_{1}+0.32 \mathrm{x}_{2}+0.69 \mathrm{x}_{3}+0.95 \mathrm{x}_{4}-3.12 \alpha \geq 8.28$

$0.55 \mathrm{x}_{1}+0.41 \mathrm{x}_{2}+0.78 \mathrm{x}_{3}+1.20 \mathrm{x}_{4}-5.04 \alpha \geq 9.36$

$0.65 \mathrm{x}_{1}+0.53 \mathrm{x}_{2}+1.02 \mathrm{x}_{3}+1.50 \mathrm{x}_{4}-4.08 \alpha \geq 8.16$

$0.82 \mathrm{x}_{1}+0.62 \mathrm{x}_{2}+1.25 \mathrm{x}_{3}+2.50 \mathrm{x}_{4}-5.40 \alpha \geq 9.6$

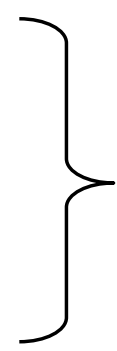


Step-6 in section 3.3 can be working out with the help of step wise procedure given below.

1. Open a new Excel sheet and type the required entities as shown in MS Excel Screen-3(a) with red colored cells and also type the formulae mentioned in table-4.4 in respective cells which are kept in green colour for easy identification.

\begin{tabular}{|c|c|c|c|c|c|c|c|c|c|c|}
\hline \multicolumn{11}{|c|}{ MS-Excel Screen -3(a) } \\
\hline 4 & A & B & C & D & $E$ & $\mathrm{~F}$ & G & H & 1 & J \\
\hline 1 & \multicolumn{9}{|c|}{ Solving MOLP provided in Equation (4.2.1) using Solver in MS-Excel } & \\
\hline 2 & \multicolumn{2}{|r|}{ Decision variables } & & \multicolumn{2}{|c|}{ Constraints } & & & & & \\
\hline 3 & $\mathrm{x} 1=$ & 0 & & Constraint1 $=$ & 0 & & & & & \\
\hline 4 & $x 2=$ & 0 & & Constraint $2=$ & 0 & & \multicolumn{3}{|c|}{ Return calculations } & \\
\hline 5 & $\mathrm{x} 3=$ & 0 & & Constraint $3=$ & 0 & & & & Probability & \\
\hline 6 & $x 4=$ & 0 & & Constraint4 (Z1)= & 0 & & $\mathrm{Z1}=$ & 0 & 40 & \\
\hline 7 & Alfa $=$ & 0 & & Constraint5 $(\mathrm{Z2})=$ & 0 & & $\mathrm{Z} 2=$ & 0 & 25 & \\
\hline 8 & & & & Constraint6 $(\mathrm{Z3})=$ & 0 & & $\mathrm{Z3}=$ & 0 & 15 & \\
\hline 9 & & & & Constraint7 $(\mathrm{Z4})=$ & 0 & & $\mathrm{Z} 4=$ & 0 & 20 & \\
\hline 10 & & & & & & & \multicolumn{2}{|c|}{ weighted returns } & 0 & \\
\hline 11 & & Alfa (Objective Function) = & 0 & & & & & & & \\
\hline 12 & & & & & & & & & & \\
\hline 13 & & & & & & & & & & \\
\hline
\end{tabular}

\begin{tabular}{|c|c|c|c|}
\hline \multicolumn{5}{|c|}{ Table-4.4: Required formulae to obtain the solution for MOLPP provided in equation (4.2.1) } \\
\hline Cel1 & Formulae to be entered & Cell & Formulae to be entered \\
\hline E3 & $=\mathrm{B} 3+\mathrm{B} 4+\mathrm{B} 5+\mathrm{B} 6$ & & \\
\hline $\mathrm{E} 4$ & $=1.76 * \mathrm{~B} 3+1.28 * \mathrm{~B} 4+1.6 * \mathrm{~B} 5+1.84 * \mathrm{~B} 6$ & & \\
\hline E5 & $=27.2 * \mathrm{~B} 3+17.5 * \mathrm{~B} 4+18.2 * \mathrm{~B} 5+18 * \mathrm{~B} 6$ & & \\
\hline E6 & $=0.35 * \mathrm{~B} 3+0.32 * \mathrm{~B} 4+0.69 * \mathrm{~B} 5+0.95 * \mathrm{~B} 6-3.12 * \mathrm{~B} 7$ & $\mathrm{H} 6$ & $=0.35 * \mathrm{~B} 3+0.32 * \mathrm{~B} 4+0.69 * \mathrm{~B} 5+0.95 * \mathrm{~B} 6$ \\
\hline $\mathrm{E} 7$ & $=0.55 * \mathrm{~B} 3+0.41 * \mathrm{~B} 4+0.78 * \mathrm{~B} 5+1.20 * \mathrm{~B} 6-5.04 * \mathrm{~B} 7$ & $\mathrm{H} 7$ & $=0.55 * \mathrm{~B} 3+0.41 * \mathrm{~B} 4+0.78 * \mathrm{~B} 5+1.20 * \mathrm{~B} 6$ \\
\hline $\mathrm{E} 8$ & $=0.65 * \mathrm{~B} 3+0.53 * \mathrm{~B} 4+1.02 * \mathrm{~B} 5+0.68 * \mathrm{~B} 6-4.08 * \mathrm{~B} 7$ & $\mathrm{H} 8$ & $=0.65 * \mathrm{~B} 3+0.53 * \mathrm{~B} 4+1.02 * \mathrm{~B} 5+0.68 * \mathrm{~B} 6$ \\
\hline $\mathrm{E} 9$ & $=0.82 * \mathrm{~B} 3+0.62 * \mathrm{~B} 4+1.25 * \mathrm{~B} 5+0.80 * \mathrm{~B} 6-5.40 * \mathrm{~B} 7$ & $\mathrm{H} 9$ & $=0.82 * \mathrm{~B} 3+0.62 * \mathrm{~B} 4+1.25 * \mathrm{~B} 5+0.80 * \mathrm{~B} 6$ \\
\hline $\mathrm{C} 11$ & $=\mathrm{B} 7$ & $\mathrm{I} 10$ & $\begin{array}{l}=\mathrm{SUM}(\mathrm{H} 6 * \mathrm{I} 6 / 100+ \\
\mathrm{H} 7 * \mathrm{I} 7 / 100+\mathrm{H} 8 * \mathrm{I} 8 / 100+\mathrm{H} 9 * \mathrm{I} 9 / 100)\end{array}$ \\
\hline
\end{tabular}

2. Open solver tool and fill up respective inputs appropriately as shown in MS Excel Screen-3(b) and click on solve which provides an optimum solution with message that solver found a solution.

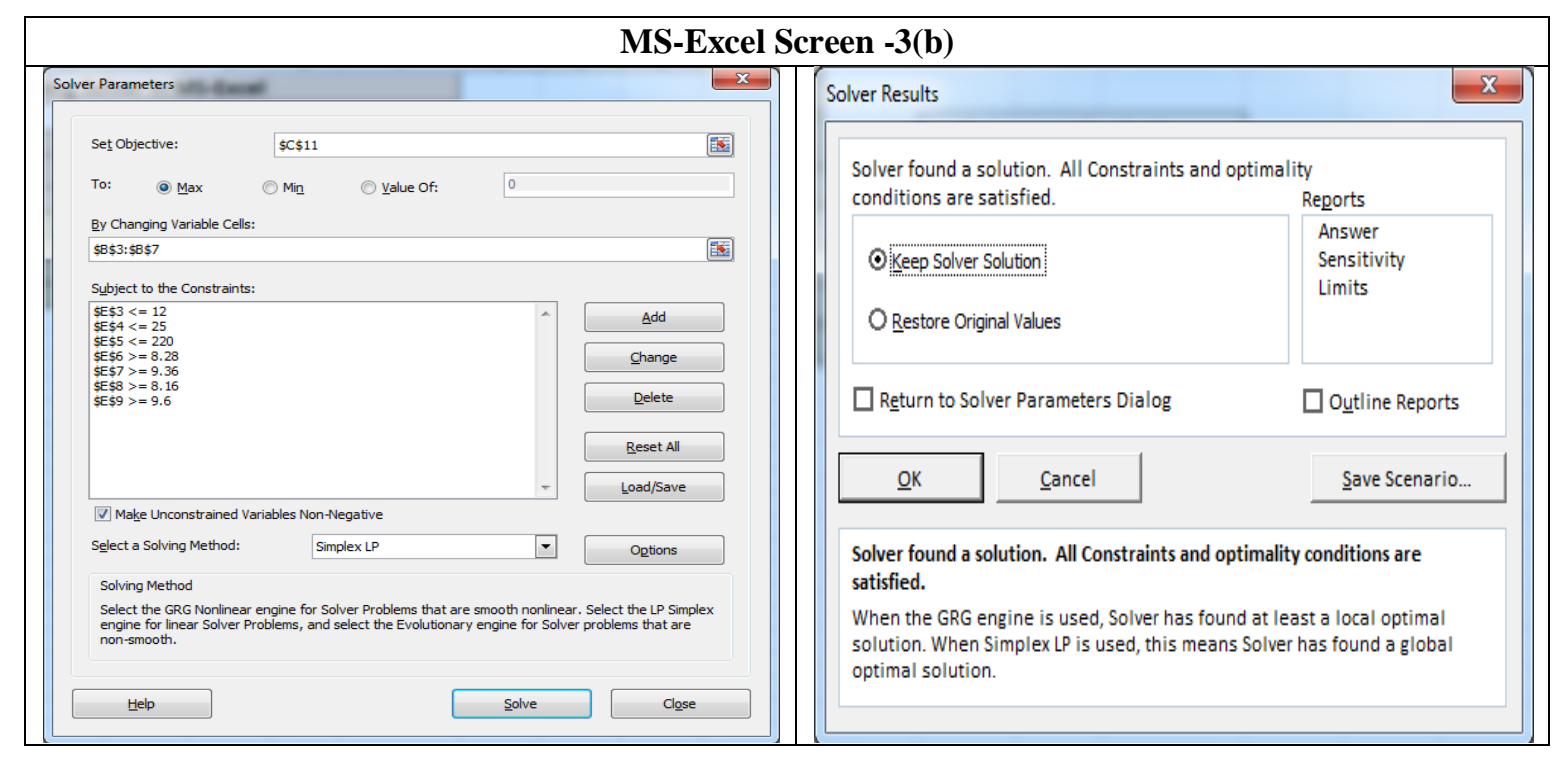


3. Then we can observe the optimum solution provided by Solver in MS-Excel Screen-3(c).

\begin{tabular}{|c|c|c|c|c|c|c|c|c|c|c|}
\hline \multicolumn{11}{|c|}{ MS-Excel Screen -3(c) } \\
\hline 4 & A & B & $\mathrm{C}$ & $\mathrm{D}$ & $E$ & $\mathrm{~F}$ & G & $\mathrm{H}$ & I & \\
\hline 1 & \multicolumn{9}{|c|}{ Solving MOLP provided in Equation (4.2.1) using Solver in MS-Excel } & \\
\hline 2 & \multicolumn{2}{|r|}{\begin{tabular}{|l|l} 
Decision variables \\
\end{tabular}} & & \multicolumn{2}{|c|}{ Constraints } & & & & & \\
\hline 3 & $\mathrm{x} 1=$ & 0 & & Constraint1 $=$ & 12 & & & & & \\
\hline 4 & $x 2=$ & 0 & & Constraint2 $=$ & 20.64 & & \multicolumn{3}{|c|}{ Return calculations } & \\
\hline 5 & $x 3=$ & 6 & & Constraint $3=$ & 217.2 & & & & Probability & \\
\hline 6 & $x 4=$ & 6 & & Constraint4 (Z1)= & 8.28 & & $\mathrm{Z} 1=$ & 9.84 & 40 & \\
\hline 7 & Alfa $=$ & 0.5 & & Constraint5 $(\mathrm{Z2})=$ & 9.36 & & $\mathrm{Z} 2=$ & 11.88 & 25 & \\
\hline 8 & & & & Constraint6 $(\mathrm{Z} 3)=$ & 8.16 & & $\mathrm{Z3}=$ & 10.2 & 15 & \\
\hline 9 & & & & Constraint7 (Z4)= & 9.6 & & $\mathrm{Z} 4=$ & 12.3 & 20 & \\
\hline 10 & & & & & & & \multicolumn{2}{|c|}{ weighted returns } & 10.896 & \\
\hline 11 & & Alfa (Objective Function) = & 0.5 & & & & & & & \\
\hline 12 & & & & & & & & & & \\
\hline 13 & & & & & & & & & & \\
\hline
\end{tabular}

4. The optimum solution which satisfies four objective functions simultaneously is $x_{1}=0, x_{2}=0, x_{3}=6$ and $\mathrm{x}_{4}=6$ which means that the farmer has to cultivate Bitter guard and tomato each at 6 acres of land in order to get guaranteed average net returns of Rs.10.896 lakhs in spite of fluctuating prices. The maximum profit is identified at the fourth set of profit coefficients which may happen only at $20 \%$ of the time.

Step-7 in section 3.3which is the guaranteed weighted average net returns can be obtained from the cell I9 automatically

\section{Conclusion}

In the present scenario of agricultural production system decision making towards certain goals is to consider compromise solution, not necessarily always a maximal solution. The present study considered some of the contributing factors for modeling the agricultural cropping pattern. The application of fuzzy concept in cropping patternfor high economic expectations hassuccessfully tackled the uncertainty and imprecision in profits. Generally market prices are influenced by several factors and attitudes of consumer as well as farmer. Obviously, financialplanning which involves multiple objectives with complex financial relationsis highly conflicting in nature. Hence, the financial world is moving towards more and more mathematical models in order to get maximum benefits out of its complexity. Moreover, agribusiness has occupied a significant place in global market and many corporate organizations are financing the farmers for smooth functioning of their supply chain. Thus, a proper land utilization and proper cropping pattern is needed at farmers' level itself. The farmer must grow the vegetable crops in a way that it should be harvested and be marketed in whole season to find at least best weighted return in view of fluctuating prices as a guaranteed profit. Thus the developed fuzzy set based quantitative methodology is capable in incorporating the uncertainty for planning model. Numerical example helps the researchers to understand the solvability of the model clearly.

\section{References}

[1]. Andres Weintraub and Carlos Romero (2006), “Operations Research Models and the Management of Agricultural and Forestry Resources: A Review and Comparison”, INFORMS, 36, 5, 446-457.

[2]. AnjeliGarg, Shiva Raj Singh(2011), Optimization under uncertainty in Agricultural production planning' UGC MRP report.

[3]. Bellman R.E., Zadeh L. A.(1970), Decision making in a fuzzy environment, Management Science 17 B, pp.141-164.

[4]. Biswas, Pal B. B.(2005), Application of fuzzy goal programming technique to land use planning in agriculture system, Omega33, pp. 391-398.

[5]. Buckley J.J.(1983), Fuzzy Programming and the Pareto Optimal Set, Fuzzy Sets and Systems 10, pp. 57-63.

[6]. Campbell J. C., Radke J., Gless J. T. and Wirtshafter R. M, (1992), “An application of linear programming and geographic information systems: cropland allocation in Antigua", Environment and Planning A, 24, pp.535-549.

[7]. Chanas S. (1989), Fuzzy Programming in multiobjective linear programming-A parametric approach, Fuzzy Sets and Systems 29, pp.303-313.

[8]. Dinesh K. Sharma, R.K. Jana, A. Gaur(2007), Fuzzy Goal programming for agricultural land allocation problems, Yugoslav Journal of Operation Research, 17, N0.1, pp.31-42.

[9]. Felix Majeke and Judith Majeke (2010), "A Farm Resource Allocation Problem: Case Study of Small Scale commercial Farmers in Zimbabwe", Journal of Sustainable Development in Africa Volume, 12, 2, pp.315-320.

[10]. Hulsurkar S., Biswal M.P., Sinha S.B.(1997), Fuzzy programming approach to multiobjective stochastic linear programming problems, Fuzzy Sets and Systems 88, pp. 173-181.

[11]. Ion RalucaAndreea and TurekRahoveanu Adrian (2012), "Linear Programming in Agriculture: Case Study in Region of Development South-Mountenia" International Journal of Sustainable Economies Management, 1, 1, 51-60. 
[12]. Itoh T., Ishii H. (2001), Fuzzy crop planning problem based on possibility measure, IEEE international fuzzy system conference.

[13]. Itoh T., Ishii H., Nanseki T. (2003), A model of crop planning under uncertainty in agriculture management, Int. J. Production Economics 81-82, pp.555-558.

[14]. LavanyaKumari.P\&VijayaKumar.K (2012). Some aspects of Operations Research using Solver, International Journal of Advanced Science, Engineering and Technology, ISSN.2319-5924, Vol.No.1, Issue.1, pp.8-16, www.bipublication.com.

[15]. Keith Butterworth (1985), "Practical Application of Linear/Integer Programming in Agriculture", Journal of Operational Research Society, Vol. 36, 2, pp.99-107.

[16]. Kruse R., Meyer K.D. (1987), Statistics with vague data, D. Riedal Publishing Company.

[17]. Lodwick W, Jamison D. and Russell S.(2000), A comparison of fuzzy stochastic and deterministic methods in Linear Programming, Proceeding of IEEE, pp.321-325.

[18]. NordinHj. Mohamad and Fatimah Said (2011), “A mathematical programming approach to crop mix problem"; African Journal of Agricultural Research Vol. 6, 1, pp.191-197.

[19]. Pal.B.B, Moitra.B.N.(2003), fuzzy goal programming approach to long term land allocation planning problem in agricultural systems: A case study, Proceedings of the fifth International Conference on Advances in Pattern recognition, Allied Publishers Pvt. Ltd., pp.441-447.

[20]. Radhakrishnan D (1962), "An application of linear programming for farm planning A case study in West Godabari District of Andhrapradesh", Indian journal of Agricultural economics, 17, 2, pp.73-82

[21]. Raj Krishna (1963), "The optimality of land allocation: A case study of the Panjab" Indian journal of Agricultural economics, 18, 1, pp.63-73.

[22]. Sakawa M. and Yano H.(1986), Interactive fuzzy decision making for multiobjective nonlinear programming using augmented minimax problems, Fuzzy Sets and Systems 20, pp.31-43.

[23]. Sante I and Crecente R (2005), "Models and Methods for Rural Land Use Planning and their Applicability in Galicia (Spain)", AESOP 05 Vienna.

[24]. Sarker R. A., TalukdarS.andAnwarulHaque A.F. M.(1997), Determination of optimum crop mix for crop cultivation in Bangladesh, Applied Mathematical Modeling 21, pp. 621-632.

[25]. Scarpari M.S and Beaclair.E.G.F(2010), "Optimized agricultural planning of Sugarcane using linear programming" Revistainvestigacionoperacional, vol. 31,no 2, pp.126-132.

[26]. Sher and Amir I.(1994), Optimization with fuzzy constraints in Agriculture production planning, Agricultural Systems 45, pp. 421 441 .

[27]. Sinha S.B., Rao K.A., and Mangaraj B.K.(1988), Fuzzy goal programming in multicriteria decision systems -A Case study in agriculture planning, Socio-Economic Planning Sciences, 22(2), pp.93-101.

[28]. Slowinski R.(1986), A multicriteria fuzzy linear programming method for water supply system development planning, Fuzzy Sets and Systems 19, pp. 217-237.

[29]. Sumpsi J.M., Francisco Amador, Carlos Romero(1996), On Farmer's Objectives: A multi criteria approach, European Journal of Operation Research 96, pp. 64-71.

[30]. Tanko L, Onyenweaku C. E. and Nwosu (2006), “Optimum crop combinations under limited resources conditions: A micro-level study in Yauri, Kebbi State, Nigeria”, NIGERAGRIC J. 37, pp.1-10.

[31]. Tarrazo M., Gutierrez L.(2000), Economic expectations, fuzzy sets and financial planning, European Journal of Operational Research. 126 ,pp.89-105.

[32]. Toyonaga T., Itoh T., Ishii H.(2005), A crop planning problem with fuzzy random profit coefficients, Fuzzy Optimization and decision making, 4,pp. 51-59.

[33]. Vasant P. M.(2003), Application of fuzzy linear programming in production planning, Fuzzy Optimization and Decision Making, 3 , pp.229-241.

[34]. Zimmermann H.J.(1978), Fuzzy programming and linear programming with several objective functions, Fuzzy Sets and Systems 1, pp.45-55. 